Geological Society, London, Special Publications Online First

\title{
Basin fragmentation controlled by tectonic inversion and basement uplift in Sierras Pampeanas and Santa Bárbara System, northwest Argentina
}

Diego Nicolas laffa, F. Sàbat, J. A. Muñoz and N. Carrera

Geological Society, London, Special Publications, first published May 16, 2013; doi 10.1144/SP377.13

$\begin{array}{ll}\begin{array}{ll}\text { Email alerting } & \text { click here to receive free e-mail alerts when } \\ \text { service } & \text { new articles cite this article }\end{array} \\ \begin{array}{ll}\text { Permission } & \text { click here to seek permission to re-use all or } \\ \text { request } & \text { part of this article }\end{array} \\ \text { Subscribe } & \begin{array}{l}\text { click here to subscribe to Geological Society, } \\ \text { London, Special Publications or the Lyell } \\ \text { Collection }\end{array}\end{array}$

How to cite click here for further information about Online First and how to cite articles

\section{Notes}




\title{
Basin fragmentation controlled by tectonic inversion and basement uplift in Sierras Pampeanas and Santa Bárbara System, northwest Argentina
}

\author{
DIEGO NICOLAS IAFFA*, F. SÀBAT, J. A. MUÑOZ \& N. CARRERA \\ GEOMODELS Research Institute, Departament de Geodinàmica i Geofísica, Facultat de \\ Geologia, Universitat de Barcelona, C/ Martí i Franquès s/n, 08028 Barcelona, Spain \\ *Corresponding author (e-mail: iaffadiego@ub.edu)
}

\begin{abstract}
The study area is located within the Central Andes, a complex region composed of different structural styles. The region is characterized by highly elevated basement cored ranges, which abruptly break the foreland plain. These ranges were uplifted mainly by deep detached high-angle faults or by the inversion of former extensional faults of the Cretaceous rift. Palaeozoic orogenies generated crustal scale discontinuities in the basement, some of them reactivated during the Andean orogeny. Sedimentary sequences and layers architecture in the basins bordering ranges recorded the tectonic evolution of the region. Basement, syn-rift, postrift and three foreland stages were interpreted in the seismic sections according to the arrangement of the horizons and the main outcropping geological units in bordering ranges. Based on seismic data sets and field data, here we document a particular style of activation of basement faults. Thick-skinned structures that are not always related to the tectonic inversion but to the reactivation of older basement anisotropies represent a paradox since they were not active during the rifting stage. A flat slab subduction and a subsequent angle recovery conditioned the structural evolution of the area.
\end{abstract}

The Andean chain is a result of the crustal deformation produced by the active subduction of the Nazca oceanic plate below the continental SouthAmerican plate. This margin was defined as an 'Andean type' according to the classification of Dewey \& Bird (1970). Several factors influenced the present structure of the Andes: the changes in the geometry and insertion angle of the subducted oceanic plate, the pre-existing discontinuities in the crust, the sedimentary cover thickness and the thermal evolution of the lithosphere (Barazangi \& Isacks 1976; Allmendinger et al. 1983; Jordan et al. 1983; Jordan \& Alonso 1987; Isacks 1988; Babeyko \& Sobolev 2005; Oncken et al. 2006).

Foreland basins are the product of mountain building and their consequent flexing of the lithosphere; the tectonic load of the newly formed relief generates space for the accumulation of sediments. The accommodation space of the formed troughs is also controlled by the sedimentary column weight, the density and the elastic thickness of the crust (Allen \& Allen 1990; DeCelles \& Giles 1996; Tassara 2005). The denudation of the bordering orogen is the main source of sediments to infill the adjacent troughs. The foreland basin of the Central Andes is mainly filled by continental sediments with only minor marine layers. The infill of this type of basin is not the typical two-stage sedimentation model, that is, marine sediments followed by continental conglomerates. Moreover, deformation does not involve a continuous propagation in a forward sequence to the inland, where the proximal parts of the basin are progressively incorporated into the fold and thrust belt frontal wedge (DeCelles \& Giles 1996). In the study area, the Andean deformation intercalated break-back episodes during its forward advance.

A set of sedimentary basins located at the Andean front was studied in order to determine the tectonic evolution of the region. To perform this study, 2D industrial seismic sections were interpreted along with field data and the compilation of published articles.

\section{Geological setting}

The study region is located in the junction of three geological provinces according to the classification of Ramos (1999), with different characteristics from one another: the Sierras Pampeanas, the Cordillera Oriental and the Santa Bárbara System (Fig. 1). The Sierras Pampeanas are made from basement cored blocks uplifted during the Andean orogeny (González Bonorino 1950; Allmendinger et al. 1983; Jordan et al. 1983). Thick-skinned structures were produced by the reactivation of deep crustal discontinuities (Mon \& Hongn 1991), 


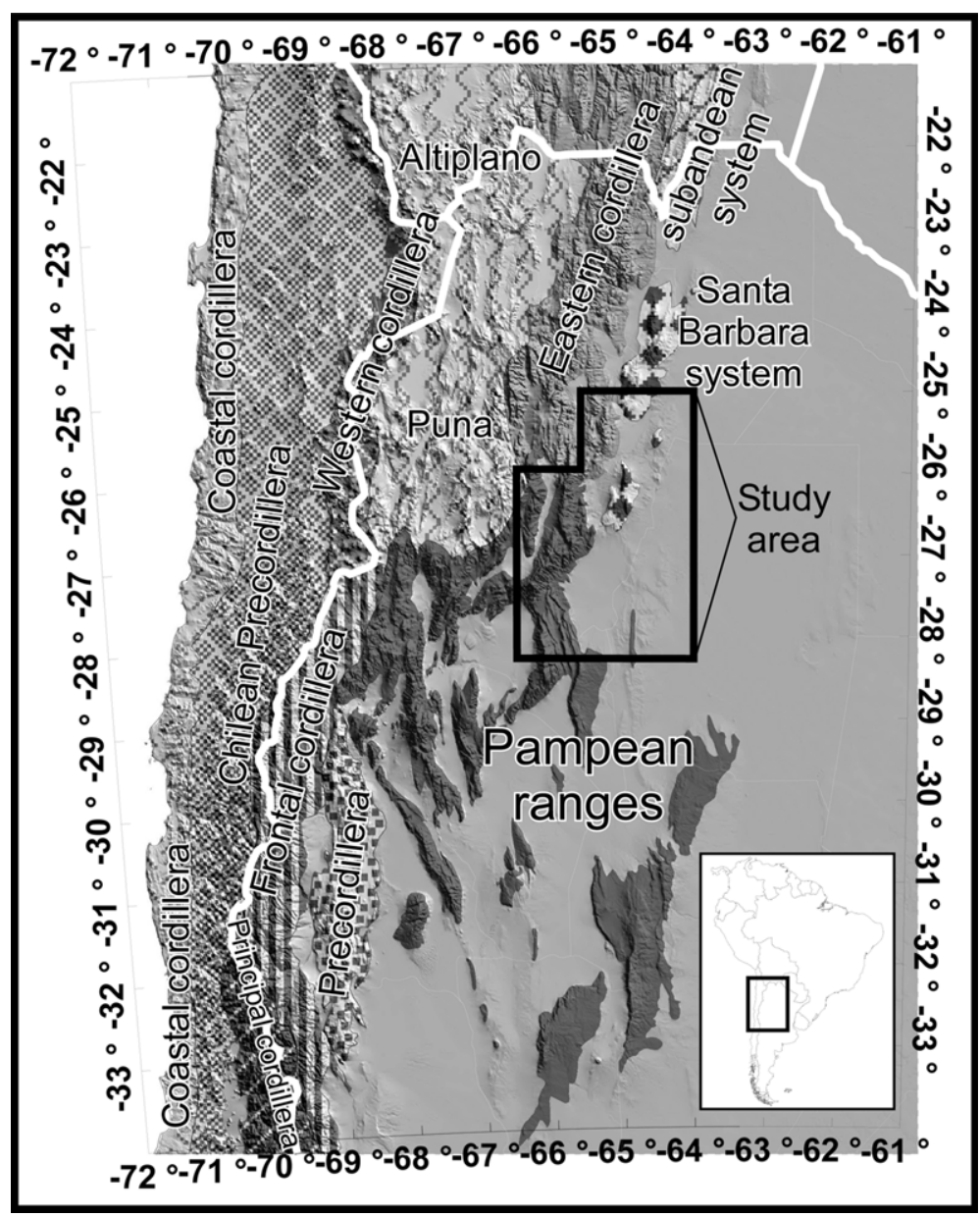

Fig. 1. Regional map of a segment of the Central Andes in NW Argentina, Chile and Bolivia. Political borders, thopography, location of the study region and main geological provinces are displayed. Figure modified from Ramos (1999) and Hilley \& Coutand (2010).

basement anisotropies and faults formed during Precambrian to Palaeozoic orogenies (Mon \& Hongn 1991; Cristallini et al. 2004; Quenardelle \& Ramos 1999). The tectonic inversion of former extensional faults played a key role in the configuration of the Santa Bárbara System, at the NE of the study area (Grier et al. 1991; Coutand et al. 2001; Kley et al. 2005; Carrera et al. 2006; Hongn et al. 2007). The Eastern Cordillera involves the inversion of Cretaceous syn-rift faults, but also basement faults that were not active during the rifting stage (Bianucci et al. 1981; Grier et al. 1991; Cristallini et al. 1997; Kley \& Monaldi 2002).

The western margin of the Gondwana supercontinent experienced several orogenic phases during Precambrian and Palaeozoic times. The accretion of allochtonous terranes in these old subductive regimes printed out a series of crustal scale discontinuities that were selectively reactivated or not in posterior tectonic events (Jordan \& Allmendinger 1986; Ramos 1988; Rapela et al. 1998).

In the Mesozoic, the opening of the southern Atlantic Ocean since the late Triassic and the beginning of the Andean subduction in the Jurassic controlled the tectonic processes in this region (Dalziel 1981; Biddle et al. 1986; Ramos 1988). During the Cretaceous a back-arc rift basin was developed with many sub-basins of different trends (Salfity \& Marquillas 1981; Monaldi et al. 2008), named the Salta Rift and constituted by a series of extensional troughs or sub-basins (Fig. 2).

The Andean orogeny with its deformation started to imprint its effects in the study region in the 


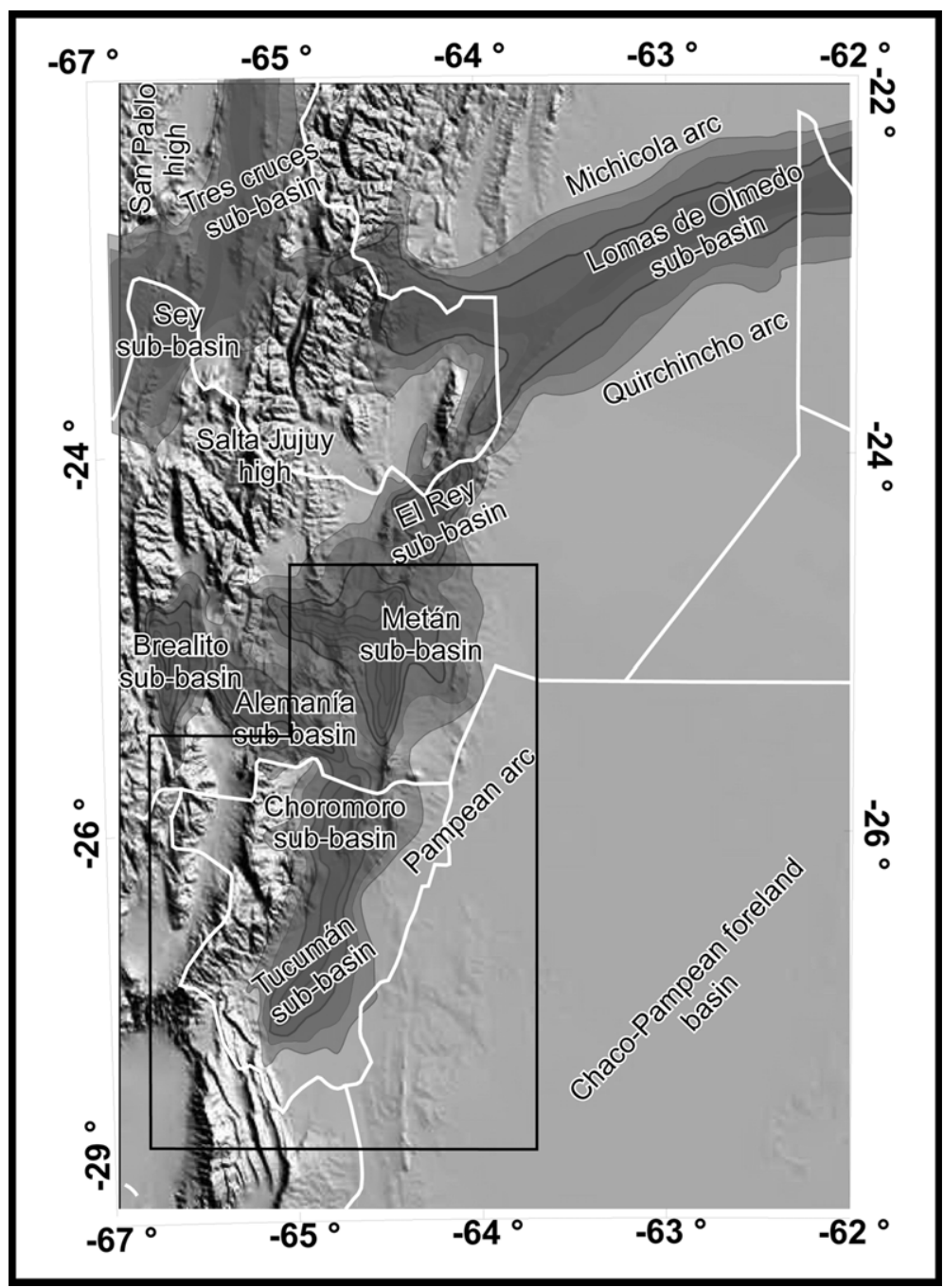

Fig. 2. Distribution of the main sub-basins that formed the Cretaceous Salta Rift and the location of the study area. The rift basin developed in a series of sub-basins that were partially connected. Note that the study area holds the Tucumán, the Choromoro and the Metán Sub-basins. Figure modified from Monaldi et al. (2008).

Eocene (Coutand et al. 2001; Carrapa et al. 2005; Carrera et al. 2006; Hongn et al. 2007). Since then, deformation has propagated towards the east but with jumps back to the west intercalated in an out-of-sequence deformation (Carrera et al. 2006; Carrera \& Muñoz 2008; Hain et al. 2011).

The Pampean flat slab subduction migrated to its present position from the north according to the Juan Fernandez Ridge geometry reconstruction and volcanic evidence (Isacks 1988; Allmendinger et al. 1997; Gutscher et al. 2000; Yáñez et al. 2002). The subduction of the Nazca plate became shallow during the Miocene owing to buoyancy produced by the subducted Juan Fernandez aseismic ridge (Pilger 1981; Kay \& Mpodozis 2002; Ramos et al. 2002; Fig. 7). The flattening of the subducted plate resulted in the migration of the volcanism to the east and also the inland propagation of the deformation front (Jordan et al. 1983). The magmatic arc migrated progressively to the east, reaching the easternmost positions at the Sierra de Aconquija in the Middle Miocene (González 1990; Kay \& Mpodozis 2002). After that time volcanism returned to the west. Until recently, the study area was in a volcanic gap (Kay \& Mpodozis 2002; Ramos et al. 2002). During the Late Miocene, 


\section{N. IAFFA $E T A L$.}

major tectonic inversions occurred, for example in the northeast segment of the Tucumán Basin (Fig. 6b). The recovery of the normal angle of subduction led to delamination of the lower crust and to the generation of widespread rhyolitic volcanism as well as formation of calderas and huge ignimbritic fields in the Puna, to the west of the study area (Coira et al. 1993; Kay \& Coira 2009).

\section{Stratigraphy}

The main stratigraphic units outcropping in region are from Precambrian to early Cambrian basement rocks up to recent sediments (Fig. 3). The different stratigraphic formations were summarized into five seismo-stratigraphic units, representing the major sequences of sedimentation (Fig. 4).

The basement is composed of low-grade schists in the south (Pankhurst \& Rapela 1998; Omarini et al. 1999; Aceñolaza et al. 2002; Aceñolaza \& Aceñolaza 2005) that were intruded by Ordovician granites (Battaglia 1982; Mon \& Hongn 1991). To the north, the basement is formed by Cambrian meta-sedimentary rocks covered by Ordovician marine deposits through an angular unconformity; these last are absent in the study region (Turner 1970; Mon \& Hongn 1991; Rossi et al. 1992). The Silurian to Devonian rocks filling the Tarija Basin and its southern continuation, the ChacoParanaense Basin (Turner 1970; Allmendinger et al. 1983; Starck \& Del Papa 2006), have only been found in the subsoil of the easternmost part of the study area and in the stratigraphic record of the drilled wells (Cristallini et al. 1997; Fernández Garrasino et al. 2005; Iaffa et al. 2011b).

Overlying the basement, a set of breccias, conglomerates, sandstones, volcanic rocks and siltstones are disposed corresponding to the syn-rift stage. These deposits were formed during the Cretaceous back-arc extension of the Salta Rift (Turner 1959; Salfity \& Marquillas 1981; Galliski \& Viramonte 1988). The formed half-graben structures were filled by continental deposits corresponding to alluvial fans, fluvial plains and debris flows (Turner 1959; Salfity \& Marquillas 1981). The layer thicknesses and grains sizes of the sediments increase in the proximities of the extensional faults.

Post-rift deposits were formed during the thermal cooling phase of the rifting, when the extensional faulting ceased and the subsidence mechanisms changed (Bianucci et al. 1981; Salfity \& Marquillas 1994). During this stage, thin sediments were deposited in layers onlapping the previous synrift beds and the basement (Comínguez \& Ramos 1995; Rodríguez Fernández et al. 1999; Kley \& Monaldi 2002; Carrera et al. 2006). Sandstones, siltstones and carbonates characterize this sequence (Moreno 1970; Bonaparte et al. 1977). Continental and marine deposits are intercalated with evaporitic facies, which highlighted the marine transgressive events and the later continentalization of the basin (Marquillas et al. 2005). Syn-rift and post-rift deposits were joined in the Salta Group, to denominate the deposits formed in the Salta Rift Basin (Salfity \& Marquillas 1981; Fig. 4).

The transition from post-rift to foreland basin stage occurred concurrent with the propagation of the Andean deformation towards the east (Jordan et al. 1983; Coutand et al. 2001; Oncken et al. 2006; Carrera \& Muñoz 2008). As the thermal subsidence ceased, the Andean orogeny was approaching the area, generating positive topography to the west, along with sediment supply to the subsiding formed trough. This transition can be recognized by the presence of an angular unconformity and stratigraphic gap of the Eocene (Reynolds et al. 2000; Del Papa et al. 2009). The newly formed topography and its associated denudation deposits reached out and covered the study area (Russo \& Serraiotto 1979; Jordan \& Alonso 1987). Three foreland basin units in this and in previous studies were defined based in the stratigraphic formations described (Bossi et al. 2001; Iaffa et al. 2011a). The three units constrain the relative ages of uplift, permitting comparison of the evolution of the different basins.

The Foreland Basin I stage started to form when local ranges had not yet been fully uplifted and the foreland basin was almost continuously covering the entire area. During this period the Andean compressive movements reached the region along with the first stages of fragmentation of the basin. Gypsum-rich levels were found intercalated within mudstones and siltstones, deposited during the middle Miocene owing to the Paraná marine transgression (Battaglia 1982; Uliana \& Biddle 1988; Gavriloff \& Bossi 1992; Ramos \& Alonso 1995). This is a very useful correlation level between the different basins and for the interpretation of the seismic sections (Iaffa et al. 2011a).

The Foreland Basin II stage was set when uplifting of the local ranges increased and the sediments sources started to approach, increasing the energy of the sedimentary system. This unit is composed of coarser sediments with respect to the Foreland Basin I stage and is constituted by sandstones and conglomerates. During this stage the foreland basin was compartmentalized into a set of sub-basins. The drainage net of the region was already differentiated by this time (Mon 2005).

The Foreland Basin III stage is a product of the denudation of the uplifted local ranges. Sediments are coarser and form bajadas, filling incised valleys and generating landslides. Conglomerates, breccias, sandstones and siltstones of alluvial fans, pediments and fluvial plains characterize this stage. 


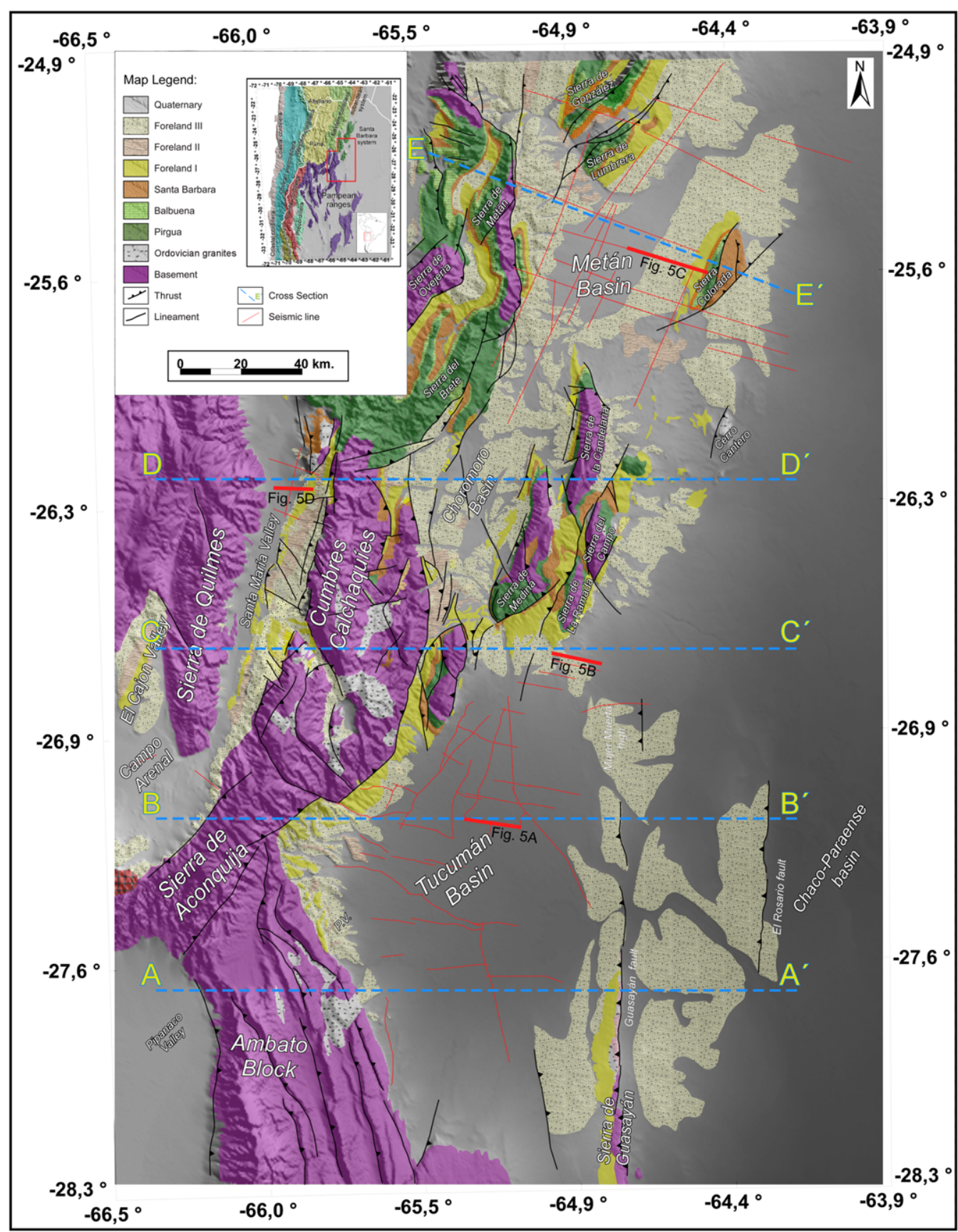

Fig. 3. Geological map of the study area where the main outcropping units and the location of the seismic sections and cross sections locations presented in this paper are displayed.

The Quaternary deposits are part of this last foreland stage and are represented by pediment levels, alluvial and colluvial deposits (Fig. 4). Rock avalanches, triggered by earthquakes, were documented on the western slope of the Sierra de Aconquija (Fauqué \& Strecker 1987). 


\section{N. IAFFA $E T A L$.}

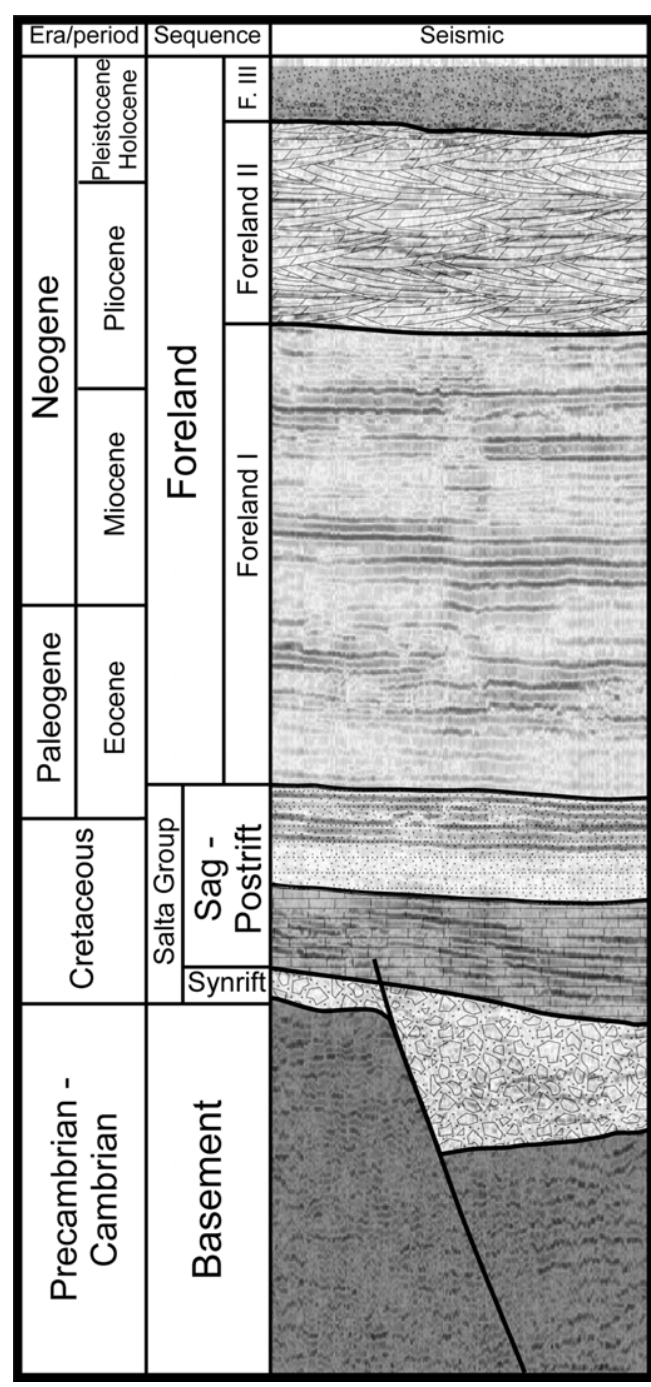

Fig. 4. Seismostratigraphic units described in the region with their corresponding ages. The basement, Salta Group and the three proposed foreland basin stages interpreted over a segment of a seismic line.

\section{Structure}

\section{Structural styles}

In order to characterize the structures that shaped the area, more than 60 seismic sections were interpreted. Four seismic sections were analysed in order to exemplify the different types of structures developed in the study region (Fig. 3). Outcropping faults and folds along with subsoil structures were also characterized according to their genesis.

The first seismic section to be described is located in middle of the Tucumán Basin, it displays west-dipping horizons thickening towards the centre of the basin covering less continuous reflections (Fig. 5a). Foreland sedimentary layers cover a series of syn-rift deposits held by normal faults produced during the Salta Rift that were not inverted by the Andean compression. Cretaceous half-grabens that preserved their original geometry were described in the eastern and southern part of the Tucumán Basin (Cristallini et al. 2004; Iaffa et al. 2011a) and in the northeastern part of the Metán Basin (Cristallini et al. 1997; Mon et al. 2005; Iaffa et al. 2011b).

In the foothills of the Sierra de La Ramada, in the NW of the Tucumán Basin (Fig. 3), the seismic section shows folded horizons describing an anticline in the western part of the section (Fig. 5b). This structure resulted from the tectonic inversion of a former Cretaceous fault, folding the syn-rift, post-rift and syn-orogenic deposits during the Andean compression. The main inverted fault is a blind thrust with two associated footwall shortcut faults (Fig. 5b). The layers were folded and truncated by an erosive surface inside the Foreland Basin II unit. This type of structure was identified in the western margin of the Tucumán Basin, in the Santa Bárbara System ranges and in the Metán Basin (Iaffa et al. 2011a,b).

The seismic section located in the middle of the Metán Basin (Fig. 3) shows a previous normal fault of the Salta Rift that was folded by a basement thrust (Fig. 5c). This structure shows that the Andean compression not only reactivated previous Cretaceous steps but also older basement discontinuities. On the eastern sector, a half-graben structure near to the surface was uplifted by highangle faults that were not inverted.

The seismic section located in the west, in the Santa María Basin (Fig. 3), displays a high-angle thrust fault, which is not related to the reactivation of Cretaceous extensional faults, but is deeply detached in the basement (Fig. 5a). This type of fault uplifts the Sierra de Guasayán, the Sierra de Aconquija and the Cumbres Calchaquíes by both flanks (Drozdzewski \& Mon 1999; Cristallini et al. 2004; Fig. 3). The Ambato Block is also uplifted by a set of NW-directed basement faults. These structures were active during the last stages of the Andean orogeny.

\section{Cross sections}

Five cross sections were drawn in order to understand the regional trends of the structure (Fig. 6). These sections are displayed along a segment of the geological map, draped on the digital elevation model and described from south to north (Fig. 3).

The first cross section $\mathrm{A}-\mathrm{A}^{\prime}$ is located in the south of the Tucumán Basin and is limited by the 


\section{BASIN FRAGMENTATION IN NW ARGENTINA}

(a)

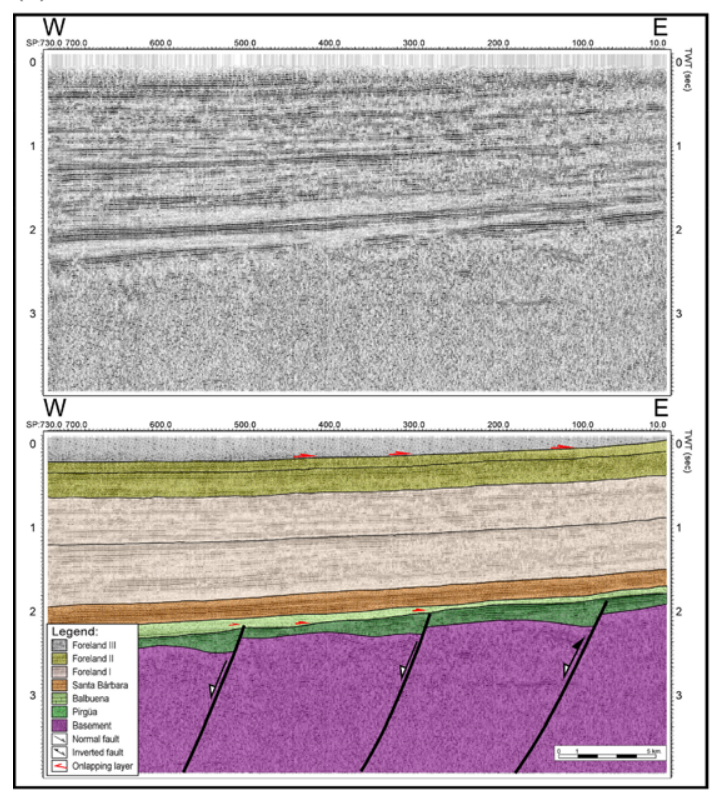

(c)

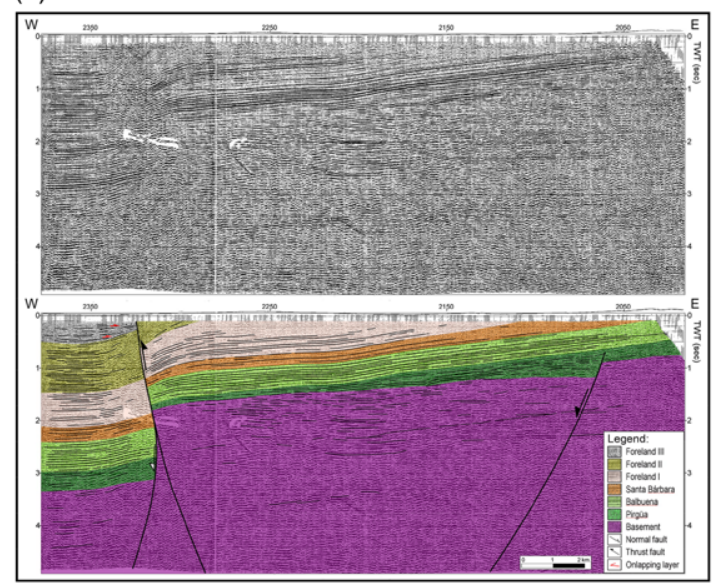

(b)

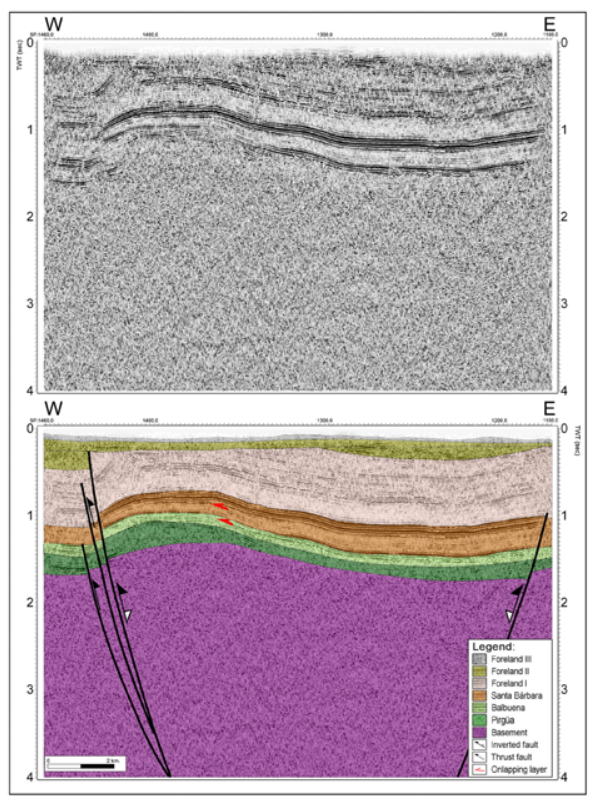

(d)

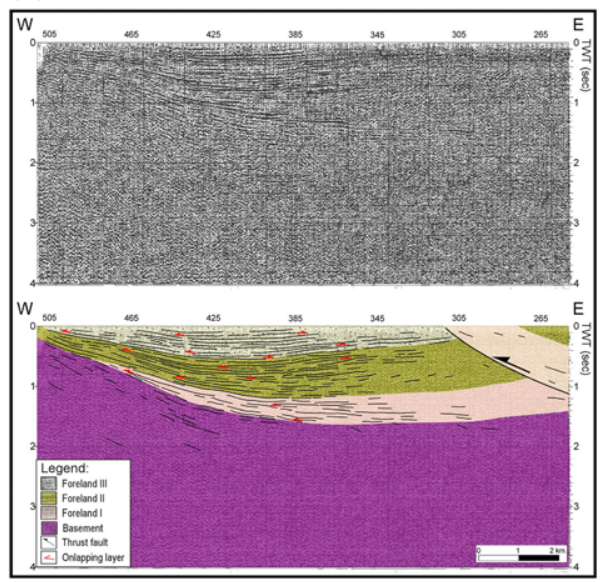

Fig. 5. Seismic sections and a sketch model exemplifying the different styles of faults in the region (see Fig. 3 for location). (a) Preserved Cretaceous extensional faults covered by west dipping foreland deposits. (b) Tectonic inversion of a former extensional graben. (c) A previous extensional fault that changed its vergence during compression. (d) Onlapping horizons related to a basement folding uplift to the west and a thin-skinned thrust detached in the sedimentary cover.

Ambato Block to the west and the Sierra de Guasayán to the east (Fig. 3). The Ambato Block is a NW-trending range formed by a series of basement blocks limited by deep detached, NE vergent thrusts (Urreiztieta et al. 1996; Cristallini et al. 2004; Roy et al. 2006). The range is $4500 \mathrm{~m}$ high, shows erosional surfaces dipping to the NE and is constituted by topographic ridges trending NW, controlling the drainage pattern (Fig. 6a).
The syn-rift deposits are thin in this sector of the Tucumán Basin with two differentiated depocentres; the western one is located at the foothills of the Ambato Block and the eastern one is set at the centre of the Tucumán Basin, close to the western fault of the Guasayán range. No syn-rift deposits were found to the east of this range (Fig. 6a). Further east, a basement east-directed thrust named 'El Rosario fault' sets the western limit of the 


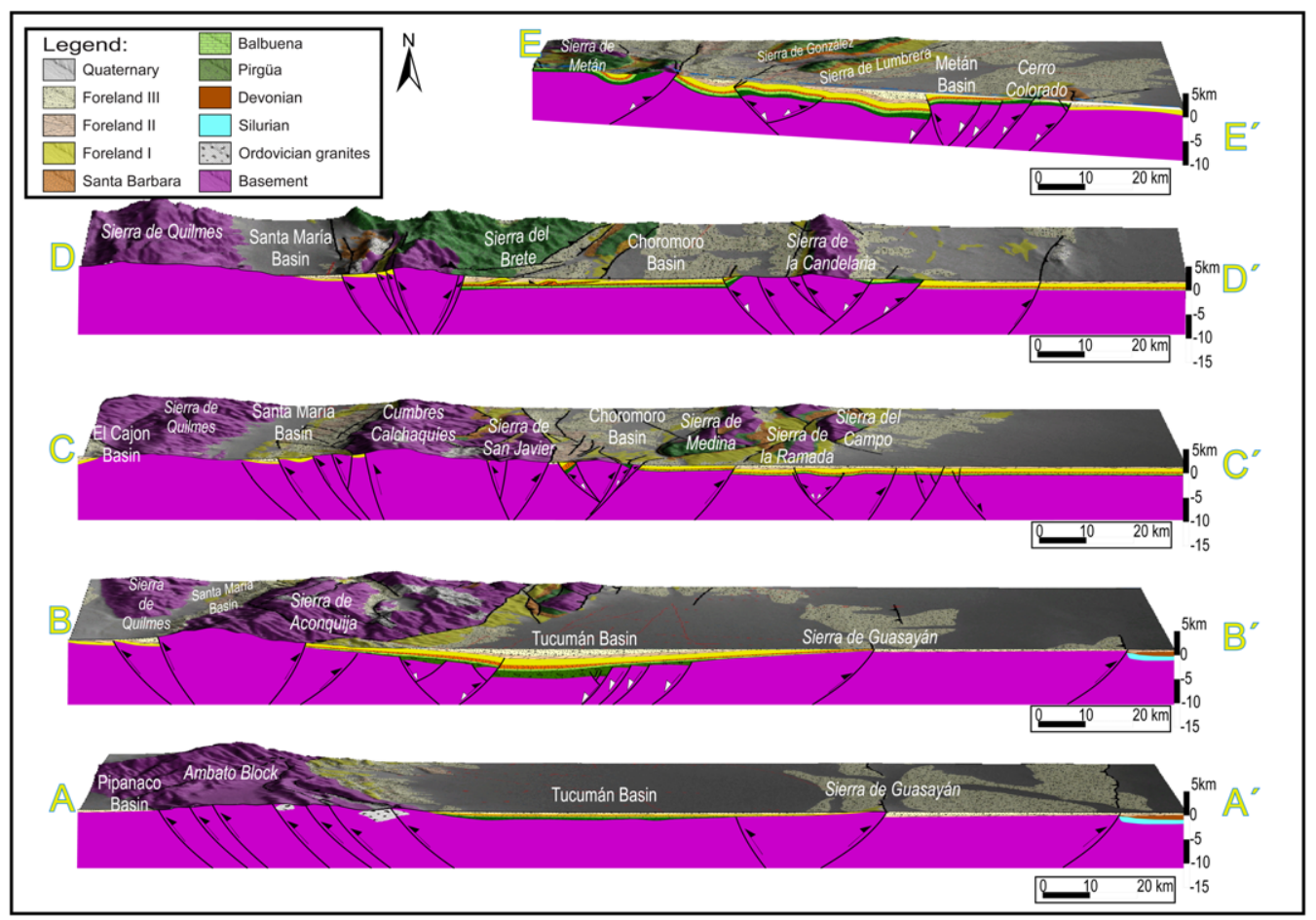

Fig. 6. Geological cross sections characterizing the different structures of the region. The structural sections are displayed along a segment of the geological map draped over the digital elevation model. See Figure 3 for location.

Palaeozoic Chaco-Paranaense Basin (Cristallini et al. 2004).

Cross section $\mathrm{B}-\mathrm{B}^{\prime}$ is located in the centre of the Tucumán Basin, with the Sierra de Aconquija on its western margin and the northern prolongation of Sierra de Guasayán to the east (Figs 2 \& 6b). The Sierra de Aconquija was described as a double vergent structure formed by deep and opposite-directed thrusts, which reactivated old basement discontinuities (Drozdzewski \& Mon 1999; Cristallini et al. 2004). On the western slope of Sierra de Aconquija, high-angle basement faults show evidence of recent activity (Fig. 6b). In this sector, no Cretaceous syn-rift or post-rift deposits are present (Strecker et al. 1989; Mortimer et al. 2007; Bossi \& Muruaga 2009). Few and small outcrops of the Salta Group deposits are found in the foothills of the eastern slope of the Sierra de Aconquija (Fig. 3). These deposits directly rest upon the basement and are overlain by foreland sequences. The section displays the maximum thickness of the Tucumán Basin (Fig. 6b), reaching over $6000 \mathrm{~m}$ depth (Iaffa et al. 2011a). The eastern part of the basin shows Cretaceous extensional halfgraben structures together with the hanging wall of the Guasayán thrust fault, which is located to the east (Cristallini et al. 2004). To the east, the Chaco-Paranaense Palaeozoic deposits lie below the foreland sequences (Fig. 6b).

The cross section $\mathrm{C}-\mathrm{C}^{\prime}$ is located in the northern part of the Tucumán Basin (Fig. 3). The western part of the cross section begins in the El Cajon Basin where foreland deposits cover the basement in the western slope of the Sierra de Quilmes (Fig. 6c). The Sierra de Quilmes is characterized by the absence of outcropping faults controlling both slopes of the range (Mortimer et al. 2007). In the eastern part of the Sierra de Quilmes, the Santa María Basin presents foreland layers directly on top of the basement with no Salta Group deposits in the stratigraphic record (Strecker et al. 1989; Bossi et al. 2001; Sobel \& Strecker 2003). The western slope of the Cumbres Calchaquíes is elevated by high-angle west-directed thrusts that expose basement rocks on Neogene foreland beds (Fig. 6c). The eastern slope of the Cumbres Calchaquíes shows deep-linked and high-angle faults involving the basement. In this area, syn-rift and post-rift deposits overlie the basement. West of the Cumbres Calchaquíes, the Sierra de San Javier is a double-vergent 'pop-up' structure, its western fault controlled by syn-rift sedimentation (Mon \& 


\section{BASIN FRAGMENTATION IN NW ARGENTINA}

Suayter 1973). In this sector of the Tucumán Basin tectonic inverted structures, where the hangingwall fold is truncated by an erosive unconformity inside the Foreland 2 sequence, constrain the age of the inversion (Fig. 5b). The Sierra de la Ramada and the Sierra de Medina are a result of this tectonic inversion (Fig. 3). In the eastern part of the section, high-angle faults that have not controlled the syn-rift extension folded the sequence not reaching the surface (Fig. 6c). These faults have reverse behaviour except for the two on the east, which are normal. These faults have a dextral strike-slip component with transpressive and transtensive features (Urreiztieta et al. 1996; Iaffa et al. 2011a).

The cross section D-D' starts from the west in the Sierra de Quilmes, ending to the east of Sierra de la Candelaria (Fig. 6d). The eastern margin of the Santa María Basin is fragmented by highangle west-directed basement thrusts. To the west, foreland deposits onlap over the Sierra de Quilmes basement. The Cumbres Calchaquíes, which has a double-vergent structure, is the western limit of the Choromoro Basin (Fig. 3). This basin holds Salta Group deposits and foreland sequences and is characterized by shallow detached faults (Abascal 2005). These thrusts produced north-trending folds and repeated the Foreland Basins II and III sequences. (Fig. 6d). To the east of the Choromoro Basin, the northern tip of the Sierra de Medina is uplifted by the inversion of its western margin. The eastern slope of the Sierra de Medina exposes the basement, as does the eastern side of the Sierra de la Candelaria (Fig. 6d). A former Cretaceous half-graben was inverted and exhumed at the eastern front of the Sierra de la Candelaria, north of the Sierra del Campo, outcropping syn-rift deposits. Further east, post-rift deposits and foreland sequences (thinner than in other sectors of the basin) were almost not affected by the Andean compression.

The cross section $E-E^{\prime}$ is located in the north of the study area, from the Sierra de Metán to the Cerro Colorado through the Metán Basin (Fig. 2). The Sierra de Metán exposes the basement and Salta Group deposits (Fig. 6e). In the Metán Basin, syn-rift layers to the centre of the basin are found at depths of $>5000 \mathrm{~m}$ (Iaffa et al. 2011b). The eastern flank of the basin is composed of a halfgraben that has been truncated by a west-directed basement thrust (Figs 5c \& 6e). The Cerro Colorado range is the result of a tectonic inversion produced by the reactivation of a fault on the eastern flank. This range is exposing syn-rift halfgraben layers thrusting over sag-foreland on the east (Iaffa et al. 2011b). No Salta Group deposits were found east of the Cerro Colorado (Mon et al. 2005).

\section{Regional analysis}

\section{Stratigraphic analysis}

The sedimentary infill of this sector of the Andes was conditioned by several tectonic stages that generated or restricted the accommodation space. Palaeozoic deposits are almost absent in the stratigraphic record of the study area; these sequences were described in the east and their absence in the studied sector may indicate the null deposition or erosion. During the Cretaceous, the syn-rift sedimentation was strongly controlled by the activity of the extensional faults, which fragmented a major part of the region in a series of uneven filled basins. The Pirgua Subgroup deposits are the most different distributed in the area (Fig. 2). After the extensional phase, a thermal subsidence phase was set and is evidenced by the distribution of post-rift deposits and the onlapping relations of the layers over the syn-rift and the basement, with a more regional and spread distribution.

Since the Andean deformation affected the study area, the subsidence was set by the tectonic load of the newly formed ranges. This process produced a new geometry in the sedimentation. During this orogenic stage, subsidence was more localized and the sedimentary column thickness was strongly diversified as the basins were compartmentalized. The relative age of uplifting of the local ranges, delimiting the basins, was constrained by the deposits affected. Growth strata were described in each basin in the interpreted seismic sections. The onlap of the layers led to estimation of the sedimentary infill record in relation to the generated topography during the sedimentation.

Published fission track data indicates an age of exhumation of the western slope of the Sierra de Aconquija which started $6 \mathrm{Ma}$ ago (Sobel \& Strecker 2003). The Sierra de Quilmes uplift was also dated by apatite fission track data and indicates a similar age of exhumation, approximately of $6 \mathrm{Ma}$. (Mortimer et al. 2007). Neotectonic activity was documented in both margins of the Sierra de Aconquija (Drozdzewski \& Mon 1999; Cristallini et al. 2004). Active seismicity was measured along with evidence in the surface of earthquakes as rock avalanches on the western slope of the Aconquija range (Fauqué \& Strecker 1987; Fig. 2).

Growth strata geometries help to define structures as active or potentially active. The growing layers were identified against the margins of the Tucumán Basin. To the west these geometries where described in the Foreland Basin II and III units and to the east for the upper foreland sequence (Fig. 6b). These relations determined that the Sierra de Aconquija and Cumbres Calchaquíes were uplifted earlier and then synchronously respect 


\section{N. IAFFA $E T A L$.}

of the Sierra de Guasayán (Fig. 7). The foreland sequences were exhumed and then eroded on the eastern margin of the basin in response to the uplifting associated with the Guasayán fault (Fig. 6b). The northern part of the basin shows growth strata geometries in the Foreland Basins II and III units and an erosive surface, which constrains the timing of the tectonic inversion and folding of an anticline at the foothills of the Sierra de La Ramada during Foreland Basin II unit. From growth strata described in the Tucumán Basin, it can be inferred that the uplifting of the Cumbres Calchaquíes and the Sierra de Medina started since the Foreland Basin II stage.

In the Metán Basin growth strata geometries were described in the Foreland Basin III unit (Fig. 5c). In addition, this unit onlaps on the Foreland Basin II that was folded before deposition of the Foreland Basin III unit (Fig. 6e).

The Santa María Basin foreland layers display horizons increasing their thickness to the east
(Fig. 5d). The Foreland deposits onlap on the Sierra de Quilmes basement, determining that this range began to uplift since the Foreland Basin I stage. Foreland Basin III deposits also show growth geometries with opposite direction (to the east), onlapping relations of these deposits on the upper Foreland Basin II and internal onlaps in the upper stage of Foreland Basin II (Fig. 5d). These relations indicate that the thin-skinned faults affecting the sedimentary cover and the thick-skinned faults uplifting the Cumbres Calchaquíes and the Sierra de Aconquija were active since the upper Foreland Basin II stage.

El Cajón Basin shows growth geometries of the layers thickening to the west since the Foreland Basin I stage, and internal onlapping geometries to the east since the upper part of the Foreland Basin II stage. These relations show that, at the western margin of the basin, the Sierra de Chango Real began to uplift before the eastern margin of the basin, that is, the western slope of the Sierra de Quilmes.

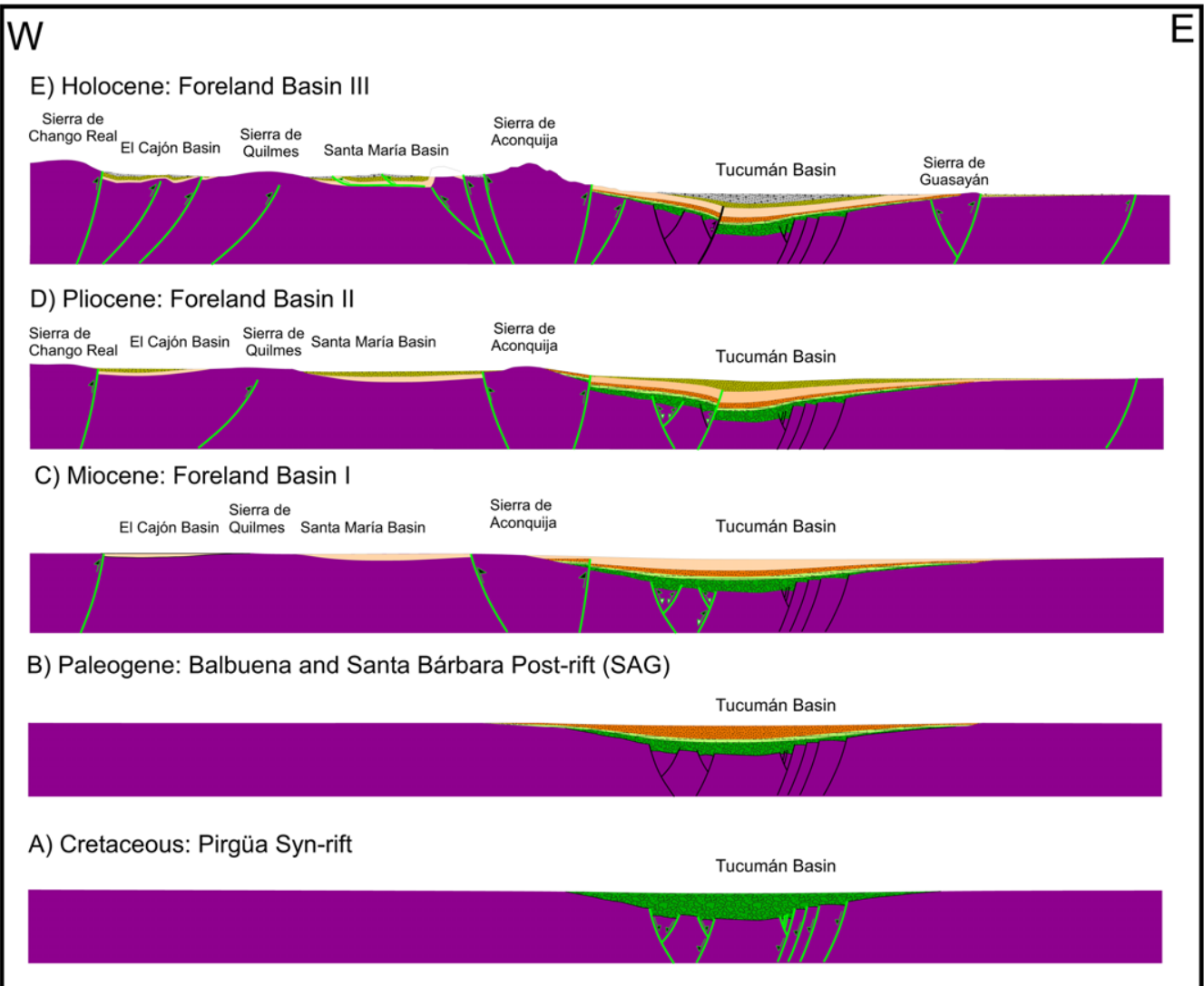

Fig. 7. Reconstruction of the tectono-stratigraphic evolution of the southern part of the study from cross section $B-B^{\prime}$. The cartoon displays five different stages of evolution, the active faults during each period and polarity of these structures at the time. In green are the active faults at each time. 


\section{BASIN FRAGMENTATION IN NW ARGENTINA}

The evidence of connection between all the basins in the study region during the foreland stage is the marine deposits product of the Paranaense transgressive event (Ramos \& Alonso 1995). This event occurred during the Foreland Basin I stage (Fig. 3). This marine ingression did not cover part of the Sierras Pampeanas ranges like the Sierra de Aconquija, the Cumbres Calchaquíes and the Sierra de Quilmes, indicating that these composed a structural high during the sea transgression (Bossi et al. 2001; Iaffa et al. 2011a).

\section{Structural analysis}

The structures in the region were classified according to their types and geometry.

Basement-related structures. Based on the interpretation of reprocessed deep reflection seismic sections, Cristallini et al. (2004) proposed for the Tucumán Basin a detachment level at about $30 \mathrm{~km}$ depth. The Sierra de Aconquija and the Cumbres Calchaquíes were set by a double-vergent fault system that is uplifting high-angle thrusts in its eastern and western margins (Drozdzewski \& Mon 1999; Cristallini et al. 2004; Iaffa et al. 2011a) (Fig. 6b). The Sierra de Guasayán shows the same structural style, with a double-vergent pop-up structure. The eastern fault of the Sierra de Guasayán has more displacement than the western one, exposing the basement in the surface (Fig. 6a). These pop-up structures have not reactivated Cretaceous extensional faults, but older crustal discontinuities (Sobel \& Strecker 2003). The Ambato Block is composed of a series of NW-trending crests, which are defined by basement discontinuities that were reactivated during the Andean deformation. The Sierra de Quilmes is a basement fold that involves a blind thrust with a deep detachment level (Fig. 7).

In the Metán Basin, two detachment levels were proposed. Cristallini et al. (1997) defined a deeper level set at $20 \mathrm{~km}$. A shallower detachment level explains the origin of the tectonic inversion of faults and folds that does not match the bigger structures and the smaller wavelength of these folds in the centre of the Metán Basin (Iaffa et al. 2011b; Fig. 6e).

Tectonic inversion structures. The Santa Bárbara System and Eastern Cordillera geological provinces are formed mainly from thick-skinned faults involving the tectonic inversion of former Salta Rift extensional faults. Inverted faults exhumed syn-rift deposits to the surface in the Sierra de San Javier, the Sierra de Medina, the Sierra de La Ramada, the Sierra del Campo and the Sierra de La Candelaria (Fig. 3). Moreover, in the Sierra de Medina, the syn-rift deposits were thrust over post-rift and foreland sequences. In the eastern margin of the Metán Basin, the Cerro Colorado exposes the morphology of a former half-graben that was fully inverted and exhumed to the surface. In the Sierra de Lumbrera and the Sierra de González, inversion structures are more complex and high-angle thrusts are involved (Fig. 6e).

The Sierra del Brete is the southern extreme of the Eastern Cordillera and is composed of an inverted former graben of the Cretaceous, with syn-rift deposits outcropping by its southeastern margin. The Sierra de Metán was originated by the tectonic inversion of a Cretaceous graben that was subsequently truncated by Andean faults, associated with basement discontinuities (Carrera \& Muñoz 2008; Fig. 6e).

Thin-skinned structures. Shallow detached thrusts were developed in specific sectors of the study area; this type of low-angle fault was described in the Santa María (Fig. 5d) and in the Choromoro basins (Fig. 6d). In the centre of the Santa María Basin, the foreland deposits were deformed by this type of structures, generating a number of tight folds; these faults trend north or NE. In the Choromoro Basin, a north-trending thin-skinned fold and thrust system affectis the foreland cover.

Strike-slip faults. Faults trending NNW to SSE with a strike-slip component were described in the Santa María Basin (Strecker et al. 1989). Evidences of strike-slip faulting were found in the northeastern margin of the Tucumán Basin (Fig. 6c). In this sector, high-angle thrusts and extensional faults were active at the same time owing to a strike-slip component. The southeastern faults uplifting the Sierra de Aconquija were described by Urreiztieta et al. (1996) as the 'Tucumán transfer Zone', being a mega-shear zone product of a dextral transpressive deformation linked to the southern Puna escape movements. The faults uplifting Sierra de Aconquija might have a dextral slip component but cannot be considered a strike-slip structure.

Strike of the faults. In the Tucumán Basin, the main faults controlling the Cumbres Calchaquíes, the Ambato Block, the Sierra de Guasayán and the Sierra de Aconquija are deep detached basement faults striking north-south, NE-SW and NNWSSE (Fig. 3). The inverted faults raising the Sierra de Medina, the Sierra de La Ramada and the Sierra del Campo strike NNE-SSW to NE-SW. In the subsurface, inverted faults strike NE-SW in the northern part of the basin, north-south in the east and east-west in the central north area. Extensional faults that were not affected by the Andean compression are mainly NNE-SSW (Fig. 8). 


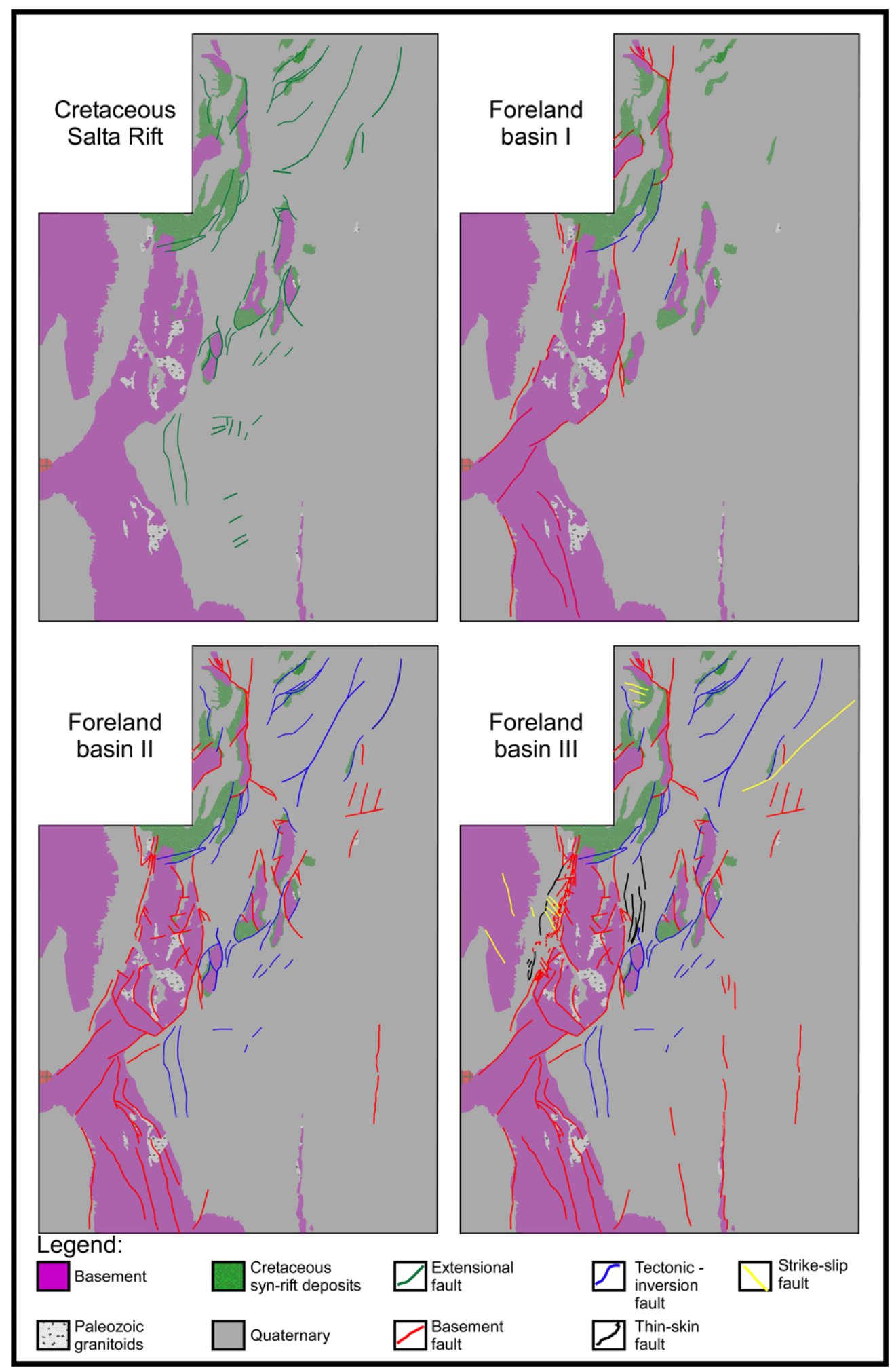




\section{BASIN FRAGMENTATION IN NW ARGENTINA}

The Metán Basin shows north-south to NNWSSE faults, which resulted from the Andean orogeny, that is, the fault uplifting Sierra de Medina and the eastern margin fault of the Cerro Colorado (Fig. 3). The NE-SW faults were extensional during the Cretaceous rift and then inverted by the Andean compression. The NNE-SSW faults experienced minor inversion or were folded depending on their dip. In the eastern margin of the basin, some extensional faults were not reactivated during the Andean compression. The Choromoro Basin is bounded by basement-related faults in the western part and tectonic inverted blocks in the southern and in the eastern ones. The faults in the basin are mainly north-south and are shallow detached in the post-rift deposits. In the Santa María Basin, the NNE-SSW trending faults are deep detached related to the basement thrust of the Sierra de Aconquija and the Cumbres Calchaquíes uplift. Faults located at the central part of the basin were detached in the sedimentary cover. The NNW-SSE faults have a strike-slip component with small displacement (Strecker et al. 1989).

\section{Discussion}

The fragmentation of the foreland basin in this sector of the Andes was controlled by the uplift of the local ranges (Figs $7 \& 8$ ). The way in which the Andean deformation compartmentalized the region can be described by using the term 'brokenforeland'. This concept was defined by Jordan et al. (1983) and describes how the basin's parts become isolated as the ranges uplift through highangle deep detached faults involving the basement. The deformational sequence of the broken foreland does not necessarily involve the propagation of the orogenic front forward to the inland in the sense of DeCelles \& Giles (1996). Although some of the western ranges of a region were uplifted prior to the eastern ones (Figs $7 \& 8$ ) and the orogenic front propagated eastwards, deformation could jump back, as was described to the north in the Eastern Cordillera (Carrera \& Muñoz 2008).

Most of the faults in the study area are mainly thick-skinned, with the exceptions of thin-skinned thrust faults described in the Santa María and Choromoro basins. The Miocene marine transgressive event deposits could act as a ductile level in the Santa María Basin. The absence of important thicknesses of marine deposits or evaporites in the basins that in posterior compressive stages could act as ductile layers is a factor contributing to the tectonic reactivation of previous structural discontinuities. Shallower detachment levels only acted in the last advanced stages of the Andean deformation, when inter-montane basins were locked by the uplifted basement ranges or inverted blocks and the system was buttressed. In the Choromoro Basin, evaporitic levels of the Santa Bárbara subgroup were the ones proposed to act as a detachment plane (Abascal 2005). The Sierra de Medina and Sierra de La Candelaria uplift locked the propagation of the deformation and therefore the shallow detachments were triggered (Fig. 6d).

The structural evolution of the study area was highly influenced by crustal-scale discontinuities inherited from older tectonic cycles. Anisotropies produced during these Precambrian to Palaeozoic tectonic cycles shaped the basement fabric, producing discontinuities that were reutilized in posterior tectonic stages. The orientations of these anisotropies were fundamental for the selection of which structure to reactivate in each stage (Fig. 8). Some of these structures were reactivated during the Salta Rift and others in the different stages of the Andean deformation. Some Cretaceous rift subbasins margins were uplifted in later stages of the Andean orogeny (Grier et al. 1991; Allmendinger et al. 1997; Kley \& Monaldi 2002; Carrapa et al. 2005; Carrera et al. 2006; Fig. 8c-d). The changes in the angle of subduction of the Nazca plate below the South American during the last 10 Ma from step to flat and then recovering produced dynamic variables in the upper crust that permitted the activation of deep detachments uplifting the basement blocks (Jordan et al. 1983; Ramos et al. 2002; Alvarado \& Ramos 2011).

The shortening rates increase to the north, with its maximums further north in the Subandean System (Kley et al. 1999; Echavarria et al. 2003; Uba et al. 2009). The sector with bigger shortening in the study region is located at both margins of the Cumbres Calchaquíes (Fig. 6). In this sector, thin-skinned structures were developed along with exhumation through deep detached faults and tectonic inversion in the southern Santa Bárbara System.

The topography generated by the tectonic inversion of the Cretaceous Salta Rift in this sector of the Andes was not developed in the Tucumán Basin and only in the margins of the Metán Basin. In the Tucumán Basin, tectonic inversion was smaller and decreased in the last foreland stage. The structures of the Tucumán Basin show a stage

Fig. 8. Schematic model of the outcropping and underground faults active during the Cretaceous and Cenozoic evolution of the studied basins. The basement and syn-rift outcropping deposits' actual shapes were used as a reference. Faults are represented in the present location. 


\section{N. IAFFA $E T A L$.}

of evolution similar to the Metán Basin first tectonic inversion, previous to the second-order structures that were shallower detached (Iaffa et al. $2011 b$ ). The future propagation of the Andean deformation towards the east might continue to produce uplifting of the Sierra de Guasayán; in that case, the Tucumán Basin will probably develop the same type of structures as described in the Metán Basin.

The Cretaceous Salta Rift Basin was a precursor of the Tucumán, Metán and Choromoro basins. The foreland basins that were set over the synrift deposits had thicker sedimentary columns. Synrift structures and deposits are absent in the western part of the study region, in El Cajón and Santa María basins, where the foreland cover is thinner and direct on the basement (Fig. 6c \& d).

\section{Concluding remarks}

The study area shows different types of structures, active in different periods that shaped the region. This evolution was set by Palaeozoic orogenic periods, Cretaceous Rift, posterior thermal cooling and finally the Andean compression with the fragmentation of the foreland basin.

\section{Stratigraphic remarks}

The stratigraphic units of the study area are the basement and the sedimentary cover, which is constituted by syn-rift, post-rift and three foreland units. The interpretation of reflection seismic sections permitted identification of three foreland seismostratigraphic units. The seismic facies were joined according to their geometrical disposition.

The different studied basins show a similar infill record, with coarsening up sequences. This resulted from a progressive uplift of the local ranges with an increase in the energy of the sedimentary environments, while the Andean deformation was propagated in the area. The foreland basins that were formed over the Salta Group deposits the Metán, Choromoro and Tucumán basins developed thicker covers with respect to the Santa María and El Cajón basins that were set directly on the basement rocks. The Miocene Paranaense marine layer is a key level older than foreland fragmentation that is very useful for correlation. It also helps to decipher which areas were structural highs at the moment of deposition, being a palaeotopographic indicator.

\section{Structural remarks}

Inherited discontinuities from older tectonic cycles strongly conditioned the structural style of the region. The Precambrian to Palaeozoic orogenies owing to subduction and terranes accretion produced foliations and crustal discontinuities that were reutilized in posterior tectonic stages. Faults uplifting the Sierras Pampeanas are deep-detached basement discontinuities reactivated or triggered by the Andean orogeny. Most of the thick-skinned faults that uplift the local ranges were not active during the Salta rifting; they started to uplift diachronically since the Foreland Basin I stage, or later, depending on their location. Double-verging structures are responsible for the raising of many ranges: the Sierra de Aconquija, the Cumbres Calchaquíes and the Sierra de Guasayán show this structural style.

The tectonic inversion of former Cretaceous Salta Rift extensional faults can be recognized in many sectors of the study area; the Santa Bárbara System ranges are a product of the selective tectonic inversion of these extensional faults. Location, orientation, vergence and dip of these discontinuities are important factors to select which faults were inverted during the Andean orogeny. The syn-rift deposits thickness was not a factor controlling the tectonic inversions.

Thin-skinned structures developed in the Santa Maria and Choromoro basins in the last stages of the deformation. These structures result from the buttressing generated with the uplifted bordering basement ranges and the propagation of the deformation within the basins detaching in the sedimentary cover.

This research is supported by the following projects: 2005-00397SGR from the Generalitat de Catalunya and Consolider-Ingenio 2010 program (CSD2006-004 'TopoIberia') and CGL2007-66431-C02-01/BTE (Modelización Estructural 4D) from the Ministerio de Educación y Ciencia of the Spanish government. The first author was funded by the AlBan scholarships programme. We would like to thank Instituto Colombiano del Petróleo, Ecopetrol and D. Bello for their invitation to assist and participate in the Meeting of Barichara. Acknowledgments go to V. Ramos, R. Rodríguez Fernandez and P. Santanach for their critical and helpful corrections of the first author's thesis that led to this paper; to E. Asensio and J. Iturralde for reading previous versions of the manuscript and their suggestions; and to Y. Basile and T. Zapata of Repsol-YPF for facilitating the seismic information.

\section{References}

Abascal, L. DEL V. 2005. Combined thin-skinned and thick-skinned deformation in the central Andean foreland of northwestern Argentina. Journal of South American Earth Sciences, 19, 75-81.

Aceñolaza, F. G. \& Aceñolaza, G. F. 2005. La Formación Puncoviscana y unidades estratigráficas vinculadas en el Neoproterozoico-Cámbrico Temprano del Noroeste Argentino. Latin American Journal of Sedimentology and Basin Analysis, 12, 65-87. 


\section{BASIN FRAGMENTATION IN NW ARGENTINA}

Aceñolaza, F. G., Miller, H. \& Toselli, A. J. 2002. Proterozoic-Early Paleozoic evolution in western South America. A discussion. Tectonophysics, 354, $121-137$.

Allen, P. A. \& Allen, J. R. 1990. Basin Analysis: Principles and Products. Blackwell Scientific Press, Oxford.

Allmendinger, R. W., Ramos, V. A., Jordan, T. E., Palma, M. \& Isacks, B. L. 1983. Paleogeography and Andean structural geometry, northwest Argentina. Tectonics, 2, 1-16.

Allmendinger, R. W., Isacks, B. L., Jordan, T. E. \& KAY, S. M. 1997. The evolution of the AltiplanoPuna plateau of the Central Andes. Annual Reviews of Earth and Planetary Sciences, 25, 139-174.

Alvarado, P. \& Ramos, V. A. 2011. Earthquake deformation in the northwestern Sierras Pampeanas of Argentina based on seismic waveform modelling. Journal of Geodynamics, 51, 205-218.

Bавеyко, A. Y. \& Sobolev, S. V. 2005. Quantifying different modes of the Late Cenozoic shortening in the Central Andes. Geology, 33, 621-624.

BARAZANGI, M. \& IsACKS, B. 1976. Spatial distribution of earthquakes and subduction of the Nazca plate beneath South America. Geology, 4, 683-692.

Battaglia, A. C. 1982. Descripción geológica de las Hojas 13f, Río Hondo, 13g, Santiago del Estero, $14 \mathrm{~g}$, El Alto, 14h, Villa San Martín, 15g, Frías. Provincias de Santiago del Estero, Catamarca y Tucumán. Servicio Geológico Nacional Buenos Aires, Argentina, $569186,80$.

Bianucci, H. A., Acevedo, O. M. \& Cerdán, J. J. 1981. Evolución tectosedimentaria del Grupo Salta en la subcuenca Lomas de Olmedo (Provincias de Salta y Formosa). VIII Congreso Geológico Argentino (San Luis) Actas, 3, 159-172.

Biddle, K. T., Uliana, M. A., Mitchum, R. M. JR, FitzGERALD, M. G. \& Wright, R. C. 1986. The stratigraphic and structural evolution of the central eastern Magallanes basin, southern South America. In: Allen, P. A. \& Homewood, P. (eds) Foreland Basins. International Association of Sedimentologists, Special Publication, 8. London, UK, 41-61.

Bonaparte, J., Salfity, J., Bossi, G. \& Powell, J. 1977. Hallazgo de dinosaurios y aves cretácicas en la Formación Lecho de El Brete (Salta), próximo al límite con Tucumán. Acta Geológica Lilloana, 14, 5-17.

Bossi, G. E. \& Muruaga, C. 2009. Eastratigrafía e inversión tectónica del 'rift' neógeno en el Campo del Arenal, Catamarca, NO Argentina. Andean Geology, 36, 311-241.

Bossi, G. E., Georgieff, S., Gavriloff, I., Ibáñez, L. \& Muruaga, C. 2001. Cenozoic evolution of the intramontane Santa María Basin, Pampean Ranges, northwestern Argentina. Journal of South American Earth Sciences, 14, 725-734.

Carrapa, B., Adelmann, D., Hilley, G., Mortimer, E., Strecker, M. R. \& Sobel, E. R. 2005. Oligocene uplift, establishment of internal drainage and development of plateau morphology in the southern Central Andes. Tectonics, 24, TC4011.

Carrera, N. \& MuÑoz, J. A. 2008. Thrusting evolution in the southern Cordillera Oriental (northern Argentine
Andes): constraints from growth strata. Tectonophysics, 459, 107-122.

Carrera, N., Muñoz, J. A., Sàbat, F., Mon, R. \& Roca, E. 2006. The role of inversion tectonics in the structure of the Cordillera Oriental (NW Argentinean Andes). Journal of Structural Geology, 28, 1921-1932.

CoIra, B. L., KaY, S. M. \& Viramonte, J. 1993. Upper Cenozoic magmatic evolution of the Argentine Puna - a model for changing subduction geometry. International Geology Review, 35, 677-720.

Comínguez, A. H. \& Ramos, V. A. 1995. Geometry and seismic expresion of the Cretaceous Salta Rift of Northwestern Argentina. In: TANKard, A. J., SuAREZ, R. \& Welsink, H. J. (eds) Petroleum Basins of South America. American Association of Petroleum Geologists, Tulsa, OK, Memoirs, 62, 325-340.

Coutand, I., Cobbold, P. R. et al. 2001. Style and history of the Andean deformation, Puna Plateau, northwestern Argentina. Tectonics, 20, 210-234.

Cristallini, E. O., Comínguez, A. \& Ramos, V. A. 1997. Deep structure of the Metán-Guachipas region: tectonic inversion in Norhwestern Argentina. Journal of South American Earth Sciences, 10, 403-421.

Cristallini, E. O., Comínguez, A., Ramos, V. A. \& Mercerat, E. D. 2004. Basement double-wedge thrusting in the Northern Sierras Pampeanas of Argentina $\left(27^{\circ} \mathrm{S}\right)$. Constraints from deep seismic reflection. In: McClay, K. R. (ed.) Thrust Tectonics and Hydrocarbon Systems. American Association of Petroleum Geologists, Tulsa, OK, Memoirs, 82, 1-26.

DALZIEL, I. W. D. 1981. Back arc extension in the southern Andes. A review and critical reappraisal. Philosophical Transactions of the Royal Society, London, 300, 319-335.

DeCelles, P. G. \& Giles, K. A. 1996. Foreland basin systems. Basin Research, 8, 105-123.

Del Papa, C., Kirschbaum, A., Powell, J., Brod, A., Hongn, F. \& Pimentel, M. 2009. Sedimentological, geochemical and paleontological insights applied to continental omission surfaces: a new approach for reconstructing Eocene foreland basin in NW Argentina. Journal of South American Earth Sciences, 10, $10-16$.

Dewey, J. F. \& BIRD, J. M. 1970. Mountain belts and the new global tectonics. Journal of Geophysical Research, 75, 2625-2647.

Drozdzewski, G. \& Mon, R. 1999. Oppositely-verging thrusting structures in the North Argentine Andes compared with the German Variscides. Acta Geológica Hispánica, 34, 185-196.

Echavarria, L., Hernandez, R., Allmendinger, R. \& REynolds, J. 2003. Subandean thrust and fold belt of northwestern Argentina; geometry and timing of the Andean evolution. AAPG Bulletin, 87, 965-985.

Fauqué, L. E. \& Strecker, M. R. 1987. Rasgos de neotectónica y avalanchas de rocas producidas por terremotos en la vertiente occidental de los nevados del Aconquija, Provincia de Catamarca, Argentina. In: Aceñolaza, F., Bossi, G. \& Toselli, A. (eds) X Congreso Geológico Argentino, Actas I. Universidad Nacional de Tucumán, Tucumán, Argentina, 219-222.

Fernández Garrasino, C., Laffitte, G. \& Villar, H. 2005. Cuenca chacoparanense. In: Chebli, G. A., Cortiñas, J. S., Spalletti, L. A., Legarretta, L. 


\section{N. IAFFA $E T A L$.}

\& Vallejo, E. L. (eds) Frontera Exploratoria de la Argentina. $6^{\circ}$ Congreso de Exploración y Desarrollo de Hidrocarburos. Instituto Argentino de Petróleo y Gas, Buenos Aires, Argentina, 97-114.

Galliski, M. A. \& Viramonte, J. G. 1988. The Cretaceous paleorift in northwestern Argentina: a petrologic approach. Journal of South American Earth Sciences, 1, 329-342.

Gavriloff, I. J. C. \& Bossi, G. E. 1992. Revisión general, análisis facial, correlación y edades de las Formaciones San José y Río Salí (Mioceno medio), provincias de Catamarca, Tucumán y Salta, República Argentina. Acta Geológica Lilloana, 17, 5-43.

GonZÁlez, O. 1990. Las volcanitas del Portezuelo de las Ánimas, sierra de Aconquija, provincias de Catamarca y Tucumán. Revista de la Asociación Geológica Argentina, 45, 386-396.

GonzÁlez Bonorino, F. 1950. Algunos problemas geológicos de las Sierras Pampeanas. Revista de la Asociación Geológica Argentina, 5, 81-110.

Grier, M. E., Salfity, J. A. \& Allmendinger, R. W. 1991. Andean reactivation of the Cretaceous Salta rift, northwestern Argentina. Journal of South American Earth Sciences, 4, 351-372.

Gutscher, M. A., Spakman, W., Bijwaard, H. \& ENGDAHL, E. R. 2000. Geodynamics of flat subduction: seismicity and tomographic constraints from the Andean margin. Tectonics, 19, 814-833.

Hain, M. P., Strecker, M. R., Bookhagen, B., Alonso, R. N., Pingel, H. \& Schmitt, A. K. 2011. Neogene to Quaternary broken foreland formation and sedimentation dynamics in the Andes of NW Argentina $\left(25^{\circ}\right.$ S). Tectonics, 30, TC2006.

Hilley, G. E. \& Coutand, I. 2010. Links between topography, erosion, rheological heterogeneity and deformation in contractional settings: insights from the central Andes. Tectonophysics, 495, 78-92.

Hongn, F., Papa, C. Del, Powell, J., Petrinovic, I., Mon, R. \& Deraco, V. 2007. Middle Eocene deformation and sedimentation in the Puna-Eastern Cordillera transition $(23-26 \mathrm{~S})$ : control by preexisting heterogeneities on the pattern of initial Andean shortening. Geology, 35, 271-274.

IafFa, D. N., SÀbat, F., Bello, D., Ferrer, O., Mon, R. \& Gutierrez, A. A. 2011a. Tectonic inversion in a segmented foreland basin from extensional to piggy back settings: the Tucumán basin in NW Argentina. Journal of South American Earth Sciences, 31, 457-474.

Iaffa, D. N., Sàbat, F., Muñoz, J. A., Mon, R. \& Gutierrez, A. A. 2011b. The role of inherited structures in a foreland basin evolution. The Metán Basin in northwest Argentina. Journal of Structural Geology, 33, 1816-1828.

IsACKs, B. L. 1988. Uplift of the Central Andean Plateau and Bending of the Bolivian Orocline. Journal of Geophysical Research, 93, 3211-3231.

Jordan, T. E. \& Allmendinger, R. W. 1986. The Sierras Pampeanas of Argentina: a modern analogue of Rocky Mountain foreland deformation. American Journal of Science, 286, 737-764.

Jordan, T. E. \& Alonso, R. N. 1987. Cenozoic stratigraphy and basin Tectonics of the Andes Mountains, $20^{\circ}-28^{\circ}$ South Latitude. The American Association of Petroleum Geologists Bulletin, 71, 49-64.
Jordan, T. E., Isacks, B., Ramos, V. A. \& AllmendinGER, R. W. 1983. Mountain building in the Central Andes. Episodes, 3, 20-26.

KAY, S. M. \& CoIrA, B. L. 2009. Shallowing and steepening subduction zones, continental lithospheric loss, magmatism, and crustal flow under the Central Andean Altiplano-Puna Plateau. In: KAY, S. M., Ramos, V. A. \& Dickinson, W. M. (eds) Backbone of the Americas: Shallow Subduction, Plateau Uplift, and Ridge and Terrane Collision. The Geological Society of America, Boulder Colorado, USA, 229-260.

KaY, S. M. \& MpodozIs, C. 2002. Magmatism as a probe to the Neogene shallowing of the Nazca plate beneath the modern Chilean flat-slab. Journal of South American Earth Sciences, 15, 39-57.

Kley, J. \& Monaldi, C. R. 2002. Tectonic inversion in the Santa Bárbara System of the central Andean foreland thrust belt, northwestern Argentina. Tectonics, 21, 1061.

Kley, J., Monaldi, C. R. \& Salfity, J. A. 1999. Alongstrike segmentation of the Andean foreland: causes and consequences. Tectonophysics, 301, 75-94.

Kley, J., Rosello, E. A., Monaldi, C. R. \& Habighorst, B. 2005. Seismic and field evidence for selective inversion of Cretaceous normal faults, Salta rift, northwest Argentina. Tectonophysics, 399, 155-172.

Marquillas, R. A., Del Papa, C. \& Sabino, I. F. 2005. Sedimentary aspects and paleoenvironmental evolution of a rift basin: Salta Group (CretaceousPaleogene), northwestern Argentina. International Journal of Earth Sciences, 94, 94-113.

Mon, R. 2005. Control tectónico de la red de dreanje de los Andes del norte Argentino. Revista de la Asociación Geológica Argentina, 60, 461-466.

Mon, R. \& Hongn, F. D. 1991. The structure of Precambrian and Lower Paleozoic basement of the Central Andes between $22^{\circ}$ and $32^{\circ} \mathrm{S}$ Lat. Geologische Rundschau, 80, 745-758.

Mon, R. \& SuAyter, L. 1973. Geología de la sierra de San Javier (provincia de Tucumán, República Argentina). Acta Geológica Lilloana, 12, 155-168.

Mon, R., Gutiérrez, A. A., Vergani, G., Pacheco, M. M. \& SÀbat, F. 2005. Estructura de la Depresión tectónica de Metán (Provincia de Salta). In: De Barrio, R. E., Etcheverry, R. O., Caballé, M. F. \& LlamBías, E. (eds) XVI Congreso Geológico Argentino., Asociación Geológica Argentina, Buenos Aires, Argentina, 73-80.

Monaldi, C. R., Salfity, J. A. \& Kley, J. 2008. Preserved extensional structures in an inverted Cretaceous rift basin, northwestern Argentina. Outcrop examples and implications for fault reactivation. Tectonics, $\mathbf{2 7}$, TC1011.

Moreno, J. A. 1970. Estratigrafía y paleogeografía del Cretácico Superior en la cuenca del Noroeste Argentino, con especial mención de los Subgrupos Balbuena y Santa Bárbara. Revista Asociación Geológica Argentina, 24, 9-44.

Mortimer, E., Carrapa, B., Coutand, I., Schoenbohm, L., Sobel, E. R., Gomez, J. S. \& Strecker, M. R. 2007. Fragmentation of a foreland basin in response to out-of-sequence basement uplifts and structural reactivation: El Cajón-Campo del Arenal basin: NW Argentina. Geological Society of America Bulletin, 119, 637-653. 


\section{BASIN FRAGMENTATION IN NW ARGENTINA}

Omarini, R., Sureda, R., Toselli, A. \& Rossi, J. 1999. Magmatismo. In: GonzÁlez Bonorino, G. OMARINI, J. \& Viramonte, J. (eds) Geología del Noroeste Argentino. XIV Congreso Geológico Argentino, Relatorio, 1, 29-40. Universidad Nacional de Salta, Salta, Argentina.

Oncken, O., Hindle, D., Kley, J., Elger, K., Victor, P. \& SchemmanN, K. 2006. Deformation of the central Andean Upper plate system - facts, fiction, and constraints for plateau models. In: ONCKEN, O., CHONG, G., Franz, G., Giese, P., Götze, H.-J., Ramos, V., Strecker, M. \& Wigger, P. (eds) The Andes - Active Subduction Orogeny. Springer, Berlin, 3-27.

Pankhurst, R. J. \& Rapela, C. W. 1998. The protoAndean margin of Gondwana: an introduction. In: Pankhurst, R. J. \& Rapela, C. W. (eds) The protoAndean Margin of Gondwana. Geological Society, London, Special Publications, 142, 1-9.

PILGER, R. H. 1981. Plate reconstructions, aseismic ridges, and low angle subduction beneath the Andes. Geological Society of America, Bulletin, 92, 448.

Quenardelle, S. \& Ramos, V. A. 1999. The ordovician western Sierras Pampeanas magmatic belt: record of Argentine Precordillera accretion. In: RAmos, V. A. \& KePPIE, D. (eds) Laurentia Gondwana Connections before Pangea. Geological Society of America, Boulder, CO, Special Papers, 336, 63-86.

Ramos, V. A. 1988. Tectonics of the Late ProterozoicEarly Paleozoic: a collisional history of Southern South America. Episodes, 11, 168-174.

RAMOs, V. A. 1999. Las provincias geológicas del territorio argentino. In: CAMINOS, R. (ed.) Geología Argentina. Instituto de Geología y Recursos Minerales, Buenos Aires, Anales, 29, 41-96.

Ramos, V. A. \& Alonso, R. N. 1995. El Mar Paranense en la Provincia de Jujuy. Revista Geológica de Jujuy, 10, 73-80.

Ramos, V. A., Cristallini, E. \& Pérez, D. J. 2002. The Pampean flat-slab of the Central Andes. Journal of South American Earth Sciences, 15, 59-78.

Rapela, C. W., Pankhurst, R. J., Casquet, C., Baldo, E., SaAvedra, J. \& Galindo, C. 1998. Early evolution of the Proto-Andean margin of South America. Geology, 26, 707-10.

Reynolds, J. H., Galli, C. I., Hernandez, R. M., Idleman, B. D., Kotila, J. M., Hilliard, R. V. \& Naeser, C. W. 2000. Middle Miocene tectonic development of the Transition Zone, Salta Province, northwestern Argentina: magnetic stratigraphy from the Metán Subgroup, Sierra de González. Geological Society of America Bulletin, 112, 1736-1751.

Rodríguez Fernández, R. L., Heredia, N., Seggiaro, R. E. \& GonzÁlez, M. A. 1999. Estructura andina de la cordillera oriental en el área de la Quebrada de Humahuaca, provincia de Jujuy, No de Argentina. Trabajos de Geología, 21, 312-332.

Rossi, J. N., Toselli, A. J. \& Durand, F. R. 1992. Metamorfismo de baja presión, su relación con el desarrollo de la cuenca Puncoviscana, plutonismo y régimen tectónico. Argentina. Estudios geológicos, 48, 279-287.

Roy, R., Cassard, D., Cobbold, P. R., Rossello, E. A., Billa, M., BAILly, L. \& LiPs, A. L. W. 2006. Predictive mapping for copper-gold magmatic-hydrothermal systems in NW Argentina: use of a regional-scale GIS, application of an expert- guided data-driven approach, and comparison with results from a continental- scale GIS. Ore Geology Reviews, 29, 260-286.

Russo, A. \& Serraiotto, A. 1979. Contribución al conocimiento de la estratigrafía terciaria en el noroeste argentino. VII Congreso Geológico Argentino, Neuquén. Actas, 1, 715-730.

Salfity, J. A. \& Marquillas, R. A. 1981. Las unidades estratigráficas cretácicas del Norte de la Argentina. In: Volkheimer, W. \& Musacchio, E. (eds) Cuencas Sedimentarias del Jurásico y Cretácico de América del Sur, 1. Comité Sudamericano del Jurásico y Crétcico, Buenos Aires, Argentina, 303-317.

Salfity, J. A. \& Marquillas, R. M. 1994. Tectonic and sedimentary evolution of the Cretaceous-Eocene Salta Group Basin, Argentina. In: SAlfity, J. A. (ed.) Cretaceous Tectonics of the Andes, Earth Evolution Sciences. Earth Evolution Sciences Monograph Series, Friedrich Vieweg \& Sohn, Braunschweig/ Wiesbaden, Germany, 266-315.

Sobel, E. \& Strecker, M. R. 2003. Uplift, exhumation and precipitation: tectonic and climatic control of late Cenozoic landscape evolution in the northern Sierras Pampeanas, Argentina. Basin Research, 15, 431-451.

Starck, D. \& Del PAPA, C. 2006. The northwestern Argentina Tarija Basin: stratigraphy, depositional systems, and controlling factors in a glaciated basin. Journal of South American Earth Sciences, 22, 169-184.

Strecker, M. R., Cerveny, P., Bloom, A. L. \& Malizia, D. 1989. Late Cenozoic tectonism and landscape development in the foreland of the Andes: Northern Sierras Pampeanas $\left(26^{\circ}-28^{\circ}\right)$, Argentina. Tectonics, 8, 517-534.

Tassara, A. 2005. Interaction between the Nazca and South American plates and formation of the Altiplano-Puna plateau: review of a flexural analysis along the Andean margin $\left(15^{\circ}-34^{\circ} \mathrm{S}\right)$. Tectonophysics, 399, 39-57.

Turner, J. C. M. 1959. Estratigrafía del cordón de Escaya y de la sierra de Rinconada (Jujuy). Revista de la Asociación Geológica Argentina, 13, 15-39.

Turner, J. C. M. 1970. The Andes of Northwestern Argentina. International Journal of Earth Sciences, 59, 1028-1063.

Uba, C., Kley, J., Strecker, M. \& Schmitt, A. K. 2009. Unsteady evolution of the Bolivian Subandean thrust belt: the role of enhanced erosion and clastic wedge progradation. Earth Planetary Science Letters, 281, $134-146$.

Uliana, M. A. \& Biddle, K. T. 1988. Mesozoic-Cenozoic paleogeographic and geodynamic evolution of southern South America. Revista Brasileira de Geociencias, 18, 72-190.

Urreiztieta, M. de, Gapais, G., Le Corre, C., Cobbold, P. R. \& Rosello, E. A. 1996. Cenozoic dextral transpression and basin development at the southern edge of the Altiplano-Puna, northwestern Argentina. Tectonophysics, 254, 17-39.

Yáñez, G., Cembrano, J., Pardo, M., Ranero, C. \& Selles, D. 2002. The Challenger-Juan FernándezMaipo major tectonic transition of the NazcaAndean subduction system at $33-34^{\circ} \mathrm{S}$ : geodynamic evidence and implications. Journal of South American Earth Sciences, 15, 23-38. 